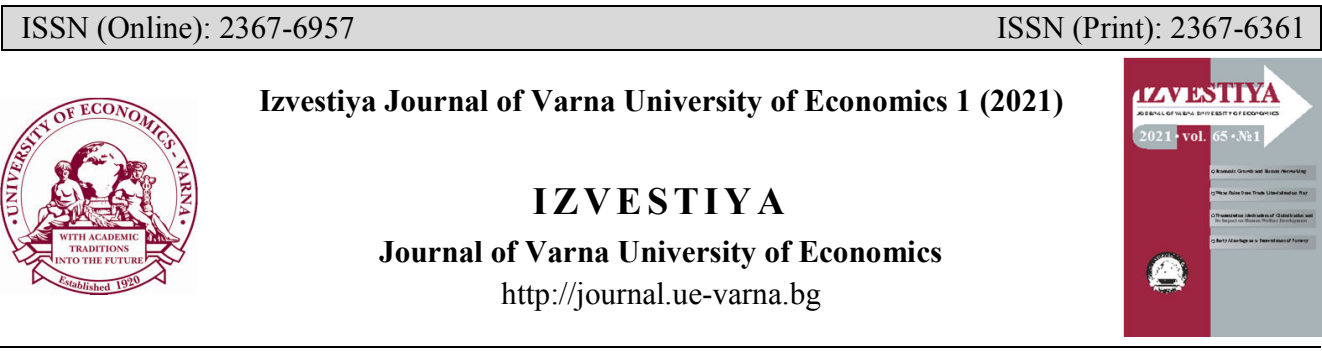

\title{
KNOWLEDGE TRANSFER AND BUSINESS PERFORMANCE: A STUDY OF MANUFACTURING ORGANIZATIONS IN OGUN STATE, THE FEDERAL REPUBLIC OF NIGERIA
}

\section{Olufemi OGUNKOYA ${ }^{1}$, Emmanuel OGUNDELE ${ }^{2}$, Adeola ADETAYO ${ }^{3}$}

1 Business Administration, Olabisi Onabanjo University, Ago- Iwoye, Ogun, Nigeria.

E-mail: ogunkoyaoa@yahoo.com

2 Business Administration, Olabisi Onabanjo University, Ago- Iwoye, Ogun, Nigeria.

E-mail: oemmanuel198@gmail.com

3 Business Administration, Olabisi Onabanjo University, Ago- Iwoye, Ogun, Nigeria. E-mail: ainaadeola59@gmail.com

JEL: M30, M31, M37 Abstract

The study examines the impact of knowledge transfer on business performance in the manufacturing sector in Nigeria based on the sample of 20 manufacturing organizations in Shagamu local government, Ogun State, Nigeria. The data used for this study were cross sectional data that were primarily sourced from the workers of those sampled manufacturing organizations through questionnaires as the instrument of data collection and responses from one hundred and fifty-three (153) respondents. The data were analyzed using Ordinary Least Square (OLS) regression technique for analysis and estimating the relationship and effect between explanatory variables and dependent variable. The findings of the study with 5\% level of significance revealed that with $\beta$ value .204 and $\mathrm{t}$-value $2.420(\mathrm{p}=$ $0.017)$, trust has a direct relationship and significant effect on business performance. With $\beta$ value .366 and $\mathrm{t}$-value $4.826(\mathrm{p}=$ $0.000)$, communication has a direct relationship and significant effect on business performance. It is, therefore, recommended that management should encourage effective communication and trust among the employees, leaders to spell-out organizations objective unambiguously and also advise that management should consider

Key words:

knowledge transfer, trust, communication, business performance. making the knowledge star workers to have a feeling of participation and input in the management process.

(C) 2021 University of Economics - Varna

Citation: OGUNKOYA, O., OGUNDELE, E., ADETAYO, A. (2021). Knowledge Transfer and Business Performance: A Study of Manufacturing Organizations in Ogun State, the Federal Republic of Nigeria. Izvestiya Journal of Varna University of Economics, 65 (1), pp. 86 - 101.

DOI: 10.36997/IJUEV2021.65.1.86 


\section{Introduction}

For value creation in any set-up, knowledge is crucial because it is the platform for both innovation and development in any organization and is becoming ever more salient (Uta \& Carlos, 2018; OECD, 2013). The widespread and rapid diffusion of information and communication technologies (ICTs) from the 1990s onwards increasingly accelerated the knowledge creation process and also added to the importance of knowledge for innovation and development (Mansell \& Wehn, 1998). Since the emergence of ICTs that enable even faster and easier sharing of data, information and knowledge, explicit and tacit knowledge transfer within organization and between organizations is germane and depends on personal interactions and collective actions to achieve specific goals and outcomes of any organization (Uta \& Carlos, 2018). However, these interactions exhibit virtually powerful bottlenecks in the transfer of knowledge process due to various (and possibly conflicting) behavioral goals and expected outcomes, structures in (dis)incentives and capabilities which have not been sufficiently examined.

The heartbeat of any organization is knowledge; therefore the effective knowledge transfer process is inherent for the creation of successful performance in projects. Thus, the key success in all aspects of human endeavor is knowledge because it has become the absolute asset for organizations (Pasaribu, Afrianti, Gumilar, Rizanti \& Rohajawati, 2017). Despite the benefits of knowledge transfer application to organizations, the literature shows that individuals share and transfer knowledge in organizations for several reasons: either for personal, egotistical altruistic or social reasons (Vivian \& Kathryn, 2017).

Notwithstanding the availability of so many research works on both the topic of knowledge transfer and business performance separately, the academic contributions that indeed examine the link between the two variables are limited in number. Considering the practical relevance of these research areas, this study represents an attempt to narrow the knowledge gap, analyzing how knowledge transfer and business performance significantly influence each other.

\subsection{Research Objectives}

The broad objective of the study is to examine the effect of knowledge transfer on business performance in manufacturing organizations in Ogun state, Nigeria. The other objectives of the study are to:

i. examine the effect of trust on business performance,

ii. determine the effect of communication on business performance. 
The research work is organized as follows; section one discussed the introduction. Section two is about the literature, while section three of the study presents the methodology. This is then followed by section four that contains the result and discussion, summary, conclusion and implication for management.

\section{Literature Review}

\subsection{Concept of Knowledge}

According to Beceral - Fernandez and Sabherwal (2010) stated that knowledge is an organized structure of facts, relationships, experience, skills and insights that generate action. Thus, it is an essential asset for organizational success and therefore embodied within the organization and should be a process via the social interchange (Sensuse, 2014). It is considered as a driver of innovation and competitive advantage within any industry and constitutes the "mind" of any organization therein. Also, knowledge is a familiarity, awareness, or understanding of someone or something, such as facts, information, descriptions, or skills, which is acquired through experience or education by perceiving, discovering or learning.

\subsubsection{Concept of Knowledge Transfer}

The significance of knowledge transfer is clearly stated in the past studies and literature (Noor, Muhd \& Norhayati, 2018; Vivian \& Kathryn, 2017; Cormican \& Dooley, 2007; Bock, Kankanhalli \& Sharma, 2006 and McDermott \& O'dell, 2001). Knowledge transfer can be defined as the process by which an organization leverages knowledge and information among members, thereby promoting learning and producing new knowledge or understanding. It is also a transformation process where information is gathered, processed, transferred and absorbed in a creative way. The knowledge transfer application other advantages to the firm according to the previous research works are well performed and process, better decision making and development of individual competencies.

Paola, Federico, Alessandria \& Laura, (2019) define knowledge transfer as the multiple ways in which knowledge from universities and public research institutions can be exploited by firms and other organizations to generate economic and social value and industry development (OECD, 2013). It embraces a wide range of activities to assist the collaborations between universities, industry and the public sector, and it involves a variety of goals, modes and channels.

According Noor, Muhd, \& Norhayati, (2018) knowledge transfer is defined as a process through which knowledge moves between a root and a recipient and where knowledge is given and practiced. Nguyen \& Burgess (2014) show that knowledge 
transferred is possible among individuals between levels in the hierarchy of the firm and between units and departments and in various companies, saying that transferring knowledge from one part to another firm is practical problems. Such as knowledge management, knowledge transfer, which aims to capture, create, organize and distribute knowledge and ensure its availability for future users.

\subsubsection{Trust}

Previous studies emphasized that trust is a vital factor to knowledge transfer within team members, groups, projects and firms and also has a significant effect on overall performance (Vivian \& Kathryn, 2017; Alessia, Wenche \& Ali, 2016; Cormican \& Dooley, 2007; Meuller, 2012; Al-Alawi, Al-Marzooqi \& Mohammed, 2007; Wickramasinghe \&Widyarante, 2012; Lin, 2007 and Costa, Roe \& Taillieu, 2001). The existence of trust is essentially needed between employees' team members in order to share their knowledge among themselves. According to Wickramasinghe \&Widyarante (2012), in case of project and organizational failures interpersonal trust has been found to remove the employees chances to blame fellow team members. However, it can be destroyed easily between team members and takes a long period to establish because it is a complicated factor that changes between people over time (Costa, Roe \& Taillieu, 2001).

\subsubsection{Communication}

Prior research suggest that communication has a positive relationship with knowledge transfer in workplace and firms and is positively related to improved performance (Vivian \& Kathryn, 2017; Alessia, Wenche \& Ali, 2016; Al-Alawi et al, 2007; Cormican \& O'Sullivan, 2003; Wickramasinghe \&Widyarante, 2012 and Crawford \& Strohkirch, 2006). Effective communication supports transfer of knowledge and assists in the achievement of objectives within the organization. It was found that an open desk design enables communication in the organizations as it also assists in the creation of strong relationship between team members (Al-Alawi et al, 2007). The factors of communities of practice and advice network have a strong impact on communication.

\subsubsection{Concept of Business Performance}

Performance can be referred to as a fact of life. In any endeavor we input momentary attention for performance to be deduced or felt if necessary (Folan, Browne \& Jagdev, 2007). Also, performance can be defined as a concept that is shown by firm's prominent employees while undertaking and fulfilling their tasks. 
Therefore, it describes how groups or individuals reach a conclusion to attain a goal. Thus, it is a way of defining where one decides and wants to go hence not an objective reality only (Lebas, 1995).

\subsection{Theoretical Review}

\section{a. Knowledge-Based View Theory}

The firm's knowledge-based theory sees knowledge as a company's most strategically important resource. Because knowledge-based resources are generally hard to imitate and socially complicated, its advocates claim that heterogeneous knowledge bases and capacities among companies are the main determinants of continuous competitive advantage and superior corporate performance.

According to the knowledge-based perspective, the strategic alliance's main advantage is access to knowledge. The Strategic Alliance contributed significantly to the implementation of knowledge by enhancing effectiveness where knowledge is incorporated and how knowledge is effectively implemented. Strategic alliance is defined as an arrangement between two or more sides to attain common objectives that pool resources and ability, to distinguish more substantially and collaborate (Teece, 1992). This activity can be a supplier-buyer relationship outsourcing agreements, technology collaboration, joint resources, new product development, shared manufacturing, and common distribution agreements across selling arrangement and franchising. Strategic alliance also could be a contractual agreement, such as franchising, cross licensing, agreement, ownership link (cross holding and joint venture).

Knowledge-based strategy is rooted in resource-based strategy to alliance with certain types of resource that impact alliance formation and focus on research and development performers. The theory stressed the use of corporate or internal organization as a means of increasing the flow of productive information (Kogut \& Zander, 1992).

\subsection{Empirical Review}

Vivian \& Kathryn, (2017) researched on the analysis of knowledge transfer practices: Insights from a medical device manufacturing organization in Ireland. The study reports on an empirical analysis of knowledge transfer practices in a large multinational organization operating in the medical technology sector in the country with the aim of ascertaining the extent and nature of knowledge sharing that takes place within this organization. To do this, the author proxy knowledge transfer using trust, communication, leadership, motivation and rewards. After which a survey 
questionnaire was created which contained 25 items and a 5-point Likert scale to measure the level of agreement with each of the items. It was found out that respondents believe that effective communication has the strongest influence on the organization's overall performance, followed by trust, then motivation, then leadership. However, rewards were found to be least important factor but still important in the overall context of knowledge sharing.

Ellis \& Zhongqi, (2016) studied factors influencing technology and knowledge transfer: Configuration recipes for Sub-Saharan Africa from United Kingdom. The study adopted configuration recipes (multivariate regression analysis) with fuzzy set qualitative comparative analysis to supplement the analysis. They found out that quality local firms should have ingrained supportive human resource management/development and knowledge management systems to enhance the quality technology and knowledge transfer. Weak institutions could also be responsible for low and poor technology knowledge transfer in Sub-Sahara Africa. Ineffective industry associations, professional bodies, and educational systems could also explain poor technology and knowledge transfer. These findings were in consistence with those of Borensztein, De Grigorio \& Lee (1998); Caves (1996); Dunning (1998); Minbaeva, Pedersen, Bjorkman, Fey \& Park (2003) and Osabutey, William \& Debrah (2014).

Moslem \& Farzaneh, (2016) studied the relationship between total quality management, knowledge transfer and knowledge diffusion in the academic settings in Shiraz University, Iran. The objective of this research is to investigate total quality management practices affecting knowledge transfer and knowledge diffusion in the academic settings. As it was a descriptive research, the research instrument was questionnaire and the methods used for data analysis were correlation and structural equation modeling by means of the path analysis. The study found out that there was a significant relationship between learning, autonomy, as the total quality management practices and knowledge transfer, and between knowledge transfer and knowledge diffusion. Also in the study, it was revealed that among the total quality management practices, learning and employee fulfillment, have the significant correlation with knowledge diffusion.

Ofobruku \& Yusuf, (2016) studied the effect of knowledge transfer on employees' performance in selected small business in Asaba, Nigeria. The objective of this research work in Africa especially in Nigeria is to examine the effect of knowledge transfer on employee performance in a small business in the industry of agriculture in Asaba. To achieve this objective, the study used survey design with qualitative and quantitative data. The population used for the work was small 
agriculture business in Asaba with two hundred and ninety-seven (297) responses from the respondents of the small agriculture businesses were analyzed using regression as statistics technique. The results of the study established the that knowledge transfer had a positive effect on employees' performance and came to a conclusion that performance of the employees in the organization will be better improved based on the level of Knowledge transfer scheme put in place within the organization.

\section{Methodology}

Survey research design was adopted for this study which contains a quantitative research approach employed using structured questionnaire as the main source of the research instrument (Perri \& Bellamy, 2012). The method of investigating the survey is justified because it helps to collect data from members of the population to decide on their current status in the population with respect to the variables (Maree, 2010). This study was carried out in Ogun state, Southwest Nigeria. It is predominantly a Yoruba speaking region, though populated by various dialects and other ethnic groups. Ogun state has an estimated population of about 5,217,716 people (National Bureau of Statistics, 2017) and the 312 registered and licensed manufacturing organizations within the state (ministry of commerce and industry, Ogun state, 2019) represent the study target population. This research was largely based on crosssectional primary data through a self- structure administered questionnaire. The researchers distributed 200 questionnaires with 15 same questions in each questionnaire among the employees within the manufacturing department/unit/section of the sampled organizations and got 175 responses returned. These represent $87.5 \%$ response rates. The analysis of data was finally based on 153 good responses after removing 21 responses that were bad. Information was gathered from the sampled manufacturing organizations workers among the 312 registered and licensed manufacturing organizations. The sample size for the study was 20 manufacturing organizations in Shagamu Local Government through the purposive sampling technique. The purpose for the sample size is based on the argument for sample size determination raised by Fraeklin \&Wallen (2002). This study adopted content validity in which the questions were subjected to scrutiny by experts. For the purposes of this study, internal consistency was emphasized and adopted. Thus, the study employed coefficient alpha (Cronbach alpha) to verify the internal consistency of each construct in order to achieve reliability of the research instrument and measurement scale. 
O. Ogunkoya, E. Ogundele, A. Adetayo. Knowledge Transfer and Business Performance: A Study of Manufacturing Organizations in Ogun State, the Federal Republic of Nigeria

\subsection{Research Hypotheses}

The following hypotheses are appropriate to the above stated objectives and were tested in this study.

$\mathrm{H}_{01}$ : There is no significant effect of trust on business performance.

$\mathrm{H}_{02}$ : There is no significant effect of communication on business performance.

\section{Result and Discussion}

\subsection{Descriptive Statistics of the Data}

\begin{tabular}{|l|r|r|r|r|c|}
\hline \multirow{2}{*}{$\begin{array}{c}\text { Explanatory } \\
\text { variables }\end{array}$} & \multicolumn{5}{|c|}{ Rate of Respondent } \\
\cline { 2 - 6 } & $\begin{array}{c}\text { Strongly } \\
\text { Disagree }\end{array}$ & Disagree & Undecided & Agree & $\begin{array}{c}\text { Strongly } \\
\text { Agree }\end{array}$ \\
\cline { 2 - 6 } & $\mathbf{1}$ & $\mathbf{2}$ & $\mathbf{3}$ & $\mathbf{4}$ & \multicolumn{1}{c|}{$\mathbf{5}$} \\
\hline Trust & $3.8 \%$ & $12.5 \%$ & $16.0 \%$ & $44.4 \%$ & $23.3 \%$ \\
\hline Communication & $2.6 \%$ & $3.5 \%$ & $5.5 \%$ & $45.9 \%$ & $42.5 \%$ \\
\hline
\end{tabular}

Source: Field Survey, (2019).

\section{Trust}

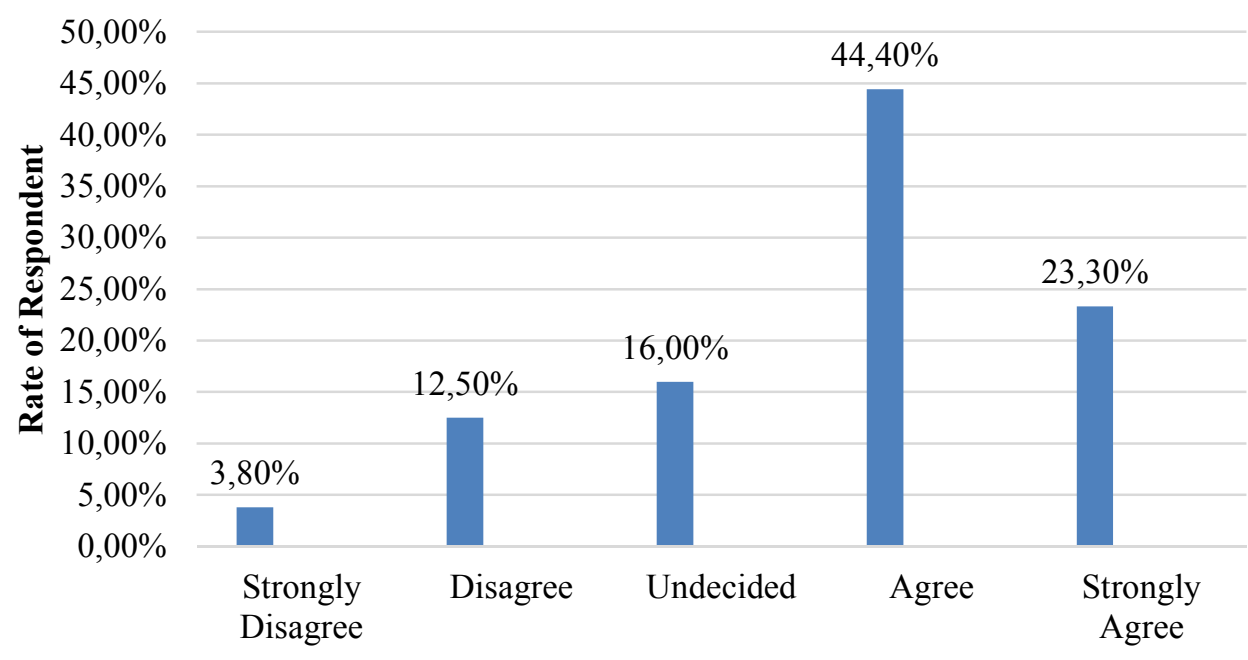

Degree of Agreement

Source: Field Survey, (2019).

Figure 4.1.1a. Trust as a measure of knowledge transfer 


\subsection{1a. Discussion of finding (Trust)}

The factor of trust as a measure of knowledge transfer relates to the existence of trust essentially needed between and among employees' team members in an organization in order to transfer their knowledge among themselves. The result table shows that $3.8 \%$ and $12.5 \%$ of the respondents strongly disagree and disagree with the factor of trust as a measure of knowledge transfer, $16 \%$ among them are indifference and undecided while $44.4 \%$ and $23.3 \%$ among the respondents agree and strongly agree with the fact that trust is a measure of knowledge transfer. It is therefore means that trust is a factor to measure knowledge transfer with $44.4 \%$ and $23.3 \%$ agree and strongly agree with the notion.

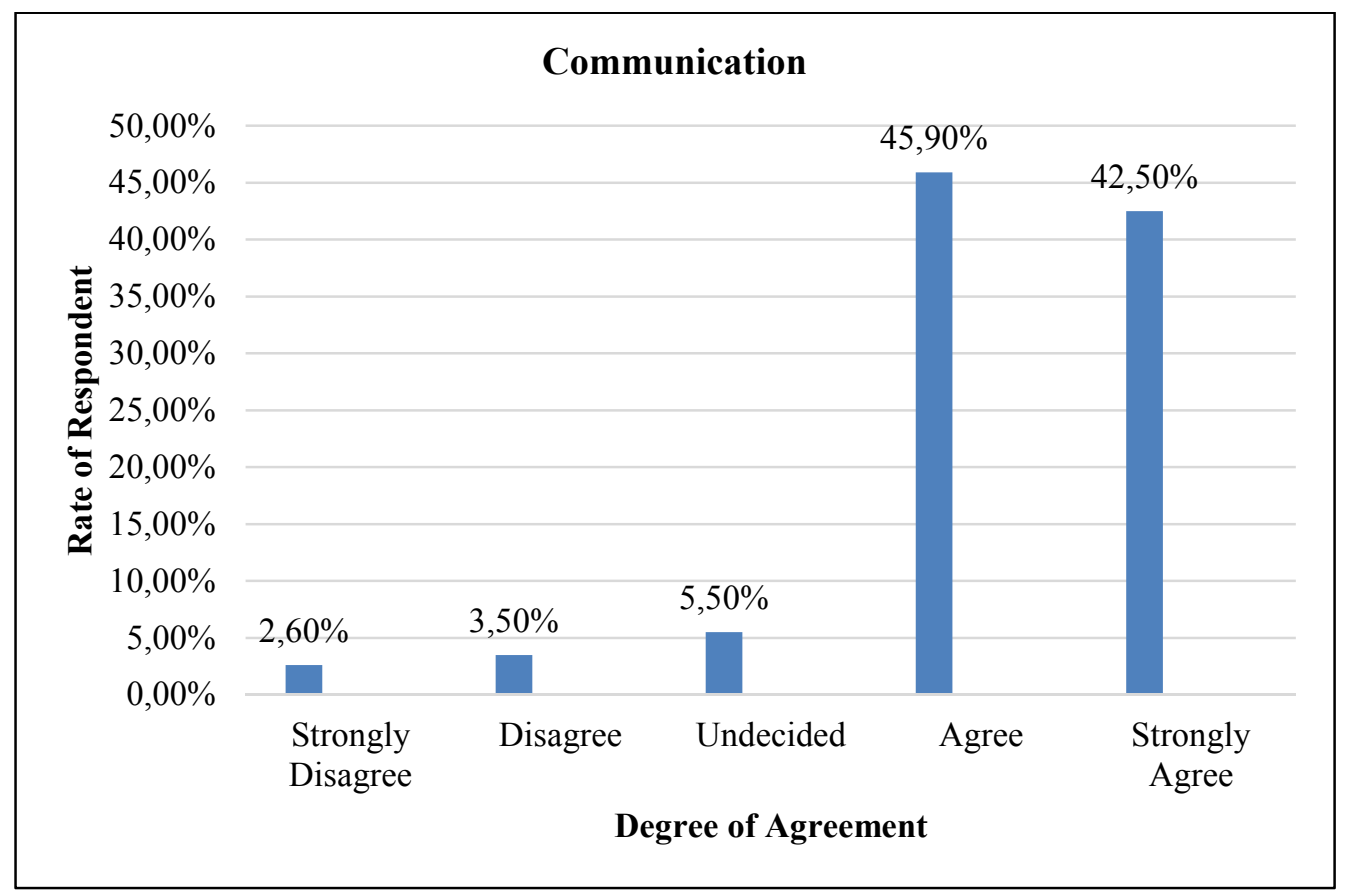

Source: Field Survey, (2019).

Figure 4.1.1b. Communication as a measure of knowledge transfer

\subsection{1b. Discussion of findings (Communication)}

The factor of communication as a measure of knowledge transfer supports and assists in the achievement of organization's objectives. It is also found that open desk 
design aids communication and as well assists in the creation of strong relationship among team members in an organization. The result reveals that $2.6 \%$ and $3.5 \%$ of the respondents strongly disagree and disagree with the concept, $5.5 \%$ among the respondents are indifferent and undecided while $45.9 \%$ and $42.5 \%$ among them agree and strongly agree that communication is a measure of knowledge transfer. Hence, with $45.9 \%$ and $42.5 \%$ of agree and strongly agree, communication is a measure of knowledge transfer.

\subsection{Test of Hypothesis 1}

4.2.1. $\mathrm{H}_{\mathbf{0} 1}$ : There is no significant effect of trust on business performance.

Table 4.2.1

\section{Summary of regression results of the effect of trust on business performance}

\begin{tabular}{|lccccc|}
\hline \multicolumn{1}{|c}{ Business Performance } & $\mathrm{B}$ & Std. Error & $\beta$ & $\mathrm{t}$ & $\mathrm{t}$ \\
& .127 & .053 & .204 & 2.420 & 0.017 \\
\hline $\mathrm{R}^{2}=.097$ & & & & & \\
F-Statistics $=3.169(\mathrm{p}=0.010)$ & & & & & \\
Durbin-Watson $=1.716$ & & & & & \\
Collinearity $=1.000$ & & & & \\
\hline
\end{tabular}

Source: Survey, 2019.

The result in table 4.2.1 reveals that there is a relationship between trust and business performance. The $\mathrm{R}^{2}(0.097)$ statistically indicates that trust brings about $9.7 \%$ variation in business performance. This shows that $90.3 \%$ variations are caused by other factors not explain in the model. The unstandardized coefficient $(\mathrm{B}=.127)$ slows that for every one (1) unit increase in trust, business performance has more chances to increase by .127 units. The $\beta$ value (.204) reveals that there is a direct relationship between trust and business performance. The $\mathrm{t}-$ value $(\mathrm{t}=2.420, \mathrm{p}=$ 0.017 ) shows that trust is a significant predictor of business performance. The $F-$ statistics $(\mathrm{F}=3.169, \mathrm{P}=0.010)$ shows that the model is significant in explaining the effect of trust on business performance. Hence, it is established that trust has significant effect on business performance. Therefore, the null hypothesis $\left(\mathrm{H}_{0}\right)$ is rejected.

\section{Durban - Watson}

The Durbin - Watson test result reveals that there is no presence of positive serial autocorrelation among the residuals because, the $d-$ value (1.632) moves towards 2 . 


\section{Collinearity}

The VIF in the table (1.158) shows how much of the variable of a coefficient estimate of a regressor has been inflated due to collinearity with other regressors. Since the VIF value above is less than 10, it shows that there is no indication of serious multi- collinearity.

\subsubsection{Testing of Hypothesis 2}

$\mathbf{H}_{\mathbf{0 2}}$ : There is no significant effect of communication on business performance

Table 4.2.2

\section{Summary of regression results of the effect of communication on business performance}

\begin{tabular}{|lccccc|}
\hline \multicolumn{7}{|c|}{ Business Performance } \\
\hline \multicolumn{1}{|c|}{ Communication } & $\mathrm{B}$ & Std. Error & $\beta$ & $\mathrm{t}$ & $\mathrm{p}$ \\
& .346 & .072 & .366 & 4.826 & 0.000 \\
\hline $\mathrm{R}^{2}=.134$ & & & & & \\
F-Statistics $=23.290(\mathrm{p}=0.000)$ & & & & & \\
Durbin-Watson $=1.716$ \\
Collinearity $=1.000$
\end{tabular}

Source: Field Survey, 2019.

Table 4.2.2 reveals that there is a relationship between communication and business performance. The $\mathrm{R}^{2}(.134)$ shows that communication brings about $13.4 \%$ variation in business performance. What this means is that $86.6 \%$ variation are caused by other factors not explain in this model. The unstandardized coefficient $(\mathrm{B}=.346)$ establishes the fact that for every one (1) unit increases in communication, business performance has chances to be increase by .346 units. The $\beta$ value .366 reveals that a direct relationship exists between communication and business performance. The $\mathrm{t}-$ value $(\mathrm{t}=4.826, \mathrm{p}=0.000)$ indicates that communication is a significant predictor of business performance. The $\mathrm{F}-$ statistics $(\mathrm{F}=23.290, \mathrm{P}=0.000)$ statistically explain that the model is significant in explaining the effect of communication on business performance. Therefore, it is establishes that communication has significant effect on business performance. Thus, the null hypothesis $\left(\mathrm{H}_{0}\right)$ is rejected.

\section{Durban-Watson}

As $d$ - value (1.716) moves towards 2, this test results reveal that there is a no presence of positive serial autocorrelation among the residuals. 
O. Ogunkoya, E. Ogundele, A. Adetayo. Knowledge Transfer and Business Performance: A Study of Manufacturing Organizations in Ogun State, the Federal Republic of Nigeria

\section{Collinearity}

The results of collinearity test (i.e. VIF) 1.000 reveals that there is no indication of serious multi collinearity in the variable of a coefficient estimate as the VIF value is less than 10 .

\subsection{Discussion of Findings}

Hypotheses 1 reveal that trust has a direct relationship and significant effect on business performance. The results which corroborated and also in agreement with the previous research by Vivian \& Kathryn (2017); Alessia, Wenche \& Ali (2016); Cormican \& Dooley (2007); Meuller (2012); Al-Alawi, Al-Marzooqi \& Mohammed (2007); Wickramasinghe \&Widyarante (2012); Lin (2007) and Costa, Roe \& Taillieu, (2001) which they all agreed that trust has effect on business performance. The finding is significant at $5 \%(\mathrm{p}=0.000)$ and as such, trust has significant effect on business performance. Hence, null hypothesis $\left(\mathrm{H}_{\mathrm{o}}\right)$ is rejected that says "there is no significant effect of trust on business performance.

Hypotheses 2 reveal that communication has a direct relationship and significant effect on business performance. The findings are in consonance with the studies of Vivian \& Kathryn (2017); Alessia, Wenche \& Ali (2016); Al-Alawi et al (2007; Cormican \& O'Sullivan (2003); Wickramasinghe \&Widyarante (2012) and Crawford $\&$ Strohkirch, (2006) as they all found positive relationship and significant effect of communication on business performance.

The finding is significant at $5 \%$ level of significance $(p=0.000)$ and as a result communication has significant effect on business performance. Therefore, null hypothesis $\left(\mathrm{H}_{\mathrm{o}}\right)$ is rejected which says "there is no significant effect of communication on business performance.

\section{Conclusion and Implication for Management}

The main purpose of this study is to critically examine the effect of knowledge transfer on business performance among the registered and licensed manufacturing organizations in Ogun state The study statement of the problem centered on knowledge assets which are all about intangible assets such as knowledge workers within a firm and how the capabilities of these 'knowledge star' must be constantly managed to create a new knowledge for better performance of such organization.

It was revealed that trust with $5 \%$ level of significant revealed that with $\beta$ value .204 and t-value $2.420(p=0.017)$, trust has a direct relationship and significant effect on business performance. The implication of this result is that, in case of business failures, interpersonal trust has been found to remove the employees chances to blame 
fellow team members. Also, the result implies that increase in trust among the employees' team members will lead to increase in business performance. Communication on the other hand, with $\beta$ value .366 and $\mathrm{t}$-value $4.826(\mathrm{p}=0.000)$, communication has a direct relationship and significant effect on business performance. The implication of this is that effective communications assist in knowledge transfer and support in the achievement of business objectives within an organization. Effective communication assists in the creation of strong relationship between team members. An increase in the effective communication will lead to an increase in the performance of business as established in this study. The findings were in consistent with the previous studies results.

Therefore, every business entity that struggles to compete and succeed in the global economy presently needs not only technology but more importantly knowledge. The organizations capacity and skill in acknowledging the worth of new knowledge, assimilate and employ it in their day to day business activities is crucial to the performance of businesses. So, in this contemporary era of business, a business entity should move to the level of knowledge and optimization of physical resources only.

\subsection{Recommendation}

Based on the findings, the following recommendations were outlined:

a. The study has shown that trust only explain $9.7 \%$ variation in business performance in Ogun state manufacturing sector and has a positive and significant effect on performance. Inasmuch as interpersonal trust has been found to remove the employees chances to blame fellow team members when objective is not achieved as well as increase in trust among the employees' team members will lead to increase in business performance then, management should create an avenue of trust among the employees and also encourage it.

b. Communication explains $13.4 \%$ variation in business performance in manufacturing sector in Nigeria. Effective communication assists in knowledge transfer and support in the achievement of business objectives within an organization and assists in the creation of strong relationship between team members. Therefore, effective communication should be encouraged either by face to face, oral or body language and any other means among the team members in an organization as business performance will further increase as a result of increase in communication. 
O. Ogunkoya, E. Ogundele, A. Adetayo. Knowledge Transfer and Business Performance: A Study of Manufacturing Organizations in Ogun State, the Federal Republic of Nigeria

\section{References}

1. Al-Alawi, I., Al-Marzooqi, Y. \& Mohammed, F. (2007). Organizational culture and knowledge sharing: Critical success factors. Journal of knowledge management, 20(11), pp. 22- 42.

2. Alessia, B., Wenche, A. \& Ali, H. (2016). Effective knowledge transfer in successful partnering projects. Energy Procedia, 96(6), pp. 218- 228.

3. Barney, J.B. (1991). Firm resources and sustained competitive advantage. Journal of Management, 17(1), pp. 99-120.

4. Becerra-Fernandez, I. \& Sabherwal, R. (2010). Knowledge Management Systems and Processes. Armonk, New York: M.E. Sharpe, Inc.; 1369.

5. Bock, G., Kankanhalli, A. \& Sharma, S. (2006). Are norms enough? The role of collaborative norms in promoting organizational knowledge seeking. European Journal of Information Systems, 15(3), pp. 357-367

6. Borensztein, E., De Grigorio, J. \& Lee, J. W. (1998). How does foreign direct investment affect economic growth? Journal of International Economics, 45(1), pp. 115-135.

7. Caves, R. E. (1996). Multinational enterprises and economic analysis (2nd ed.). Cambridge: Cambridge University Press.

8. Cormican, K. \& O'Sullivan, D. (2003). A scorecard for supporting enterprise knowledge management. Journal of Information and Knowledge Management, 3(2), pp. 191-201.

9. Cormican. K. \& Dooley L. (2007). Knowledge sharing in a collaborative networked environment. Journal of Information and Knowledge Management, 20(1), pp. 105- 115 .

10. Costa, A., Roe, E. \& Taillieu, T. (2001). Trust within teams: The relation with performance effectiveness. European journal of work and organizational psychology, 16(10), pp. 225- 244.

11. Dunning, J. H. (1998). Location and the multinational enterprise. Journal of International Business Studies, 29(1), pp. 45-66.

12. Ellis, L. C. O. \& Zhongqi, J. (2016). Factors influencing technology and knowledge transfer: Configurational recipes for Sub-Saharan Africa. Journal of Business Research, 69(6), pp. 5390-5395.

13. Folan, P., Browne, J. \& Jagdev, H. (2007). Performance: Its meaning and content for today's business research. Computers in Industry, 58(1), pp. 605-620.

14. Kogut, B. (1988). Joint venture: theoretical and empirical perspective. Strategic Management Journal, 9(1), pp. 319-332. 
15. Kogut, B. \& Zander, U. (1992). Knowledge of the firm, combinative capabilities, and the replication of technology. Organization Science, 3(1), pp. 383- 397.

16. Lebas, M. J. (1995). Performance measurement and performance management. International Journal of Production Economics, 41(1), pp. 23-35.

17. Lin, H. (2007). Effects of extrinsic and intrinsic motivation on employee knowledge sharing intentions. Journal of information science, 3(3), pp. 135-149.

18. Mansell, R. \&Wehn, U. (1998). Knowledge Societies Information Technology for Sustainable Development. Oxford University Press, Oxford.

19. Maree, J., G. (2010). The career interest profile (2nd ed.). Randburg, South Africa: Jopie van Rooyen and Partners.

20. McDermott, R. \& O'Dell, C. (2001). Overcoming cultural barriers to sharing knowledge. Journal of Knowledge Management, 1(5), pp. 76-85.

21. Meuller, J. (2012). Interactive relationship of corporate culture and knowledge management: A review. Review of Managerial Science, 2(6), pp. 183-201.

22. Minbaeva, D., Pedersen, T., Björkman, I., Fey, C. F. \& Park, H. J. (2003). MNC knowledge transfer, subsidiary absorptive capacity, and HRM. Journal of International Business Studies, 34 (6), pp. 586-599.

23. Moslem, A. \& Farzaneh, E. (2016). Relationship between Total Quality Management, knowledge Transfer and knowledge Diffusion in the academic settings. Procedia - Social and Behavioral Sciences, 230(6), pp. $104-111$.

24. Noor, A. H. M. H., Muhd, N. M. N. \& Norhayati, H. (2018). Knowledge Transfer Practice in Organizational. International Journal of Academic Research in Business and Social Sciences, 7(8), pp. 750-761.

25. OECD, (2013). Supporting Investment in Knowledge Capital, Growth and Innovation. OECD, Paris.

26. Ofobruku, S. A. \& Yusuf, B. M. (2016). Effect of knowledge transfer on employees' Performance in selected small business in asaba, Nigeria. Arabian Journal of Business and Management Review (Oman Section), 6(2), pp. 1-13.

27. Osabutey, E. L. C., Williams, K. \& Debrah, A. Y. (2014). The potential for technology and knowledge transfers between foreign and local firms: A study of the construction industry in Ghana. Journal of World Business, 49(4), pp. 560-571.

28. Paola, G., Federico, M., Alessandra, S. \& Laura, T. (2019). The strategic orientation of universities in knowledge transfer activities. Technological Forecasting \& Social Change, 138(3), pp. 261-278.

29. Pasaribu, B. I., Afrianti, A., Gumilar, G. G., Rizanti, H. P. \& Rohajawati S. (2017). Knowledge Transfer: A Conceptual Model and Facilitating Feature in Startup Business. Procedia Computer Science, 116(7), pp. 259-266. 
O. Ogunkoya, E. Ogundele, A. Adetayo. Knowledge Transfer and Business Performance: A Study of Manufacturing Organizations in Ogun State, the Federal Republic of Nigeria

30. Perri, P. \& Bellamy, C. (2012). Principles of Methodology: Research Design in Social Science. London: SAGE Publications Ltd.

31. Sensuse, D. (2014). Models and Frameworks of Knowledge Management: A Literature Review. In: International Conference on Information Science. Electronics and Electrical Engineering. IEEE; pp. 1166-70.

32. Teece, D. J. (1992). Competition, cooperation, and innovation: Organizational arrangements for regimes of rapid technological progress. Journal of Economic Behavior and Organization, 18(1), pp. 1-25.

33. Uta, W. \& Carlos, M. (2018). Knowledge transfer dynamics and innovation: Behaviour, interactions and aggregated outcomes. Journal of Cleaner Production, 171(2018), 556-568.

34. Vivian, D. \& Kathryn, C. (2017). Analysis of knowledge transfer practices: Insights from a medical device manufacturing organization. Procedia Computer Science, 121(7), 186-193.

35. Wickramasinghe, V. \& Widyarante, R. (2012). Effects of interpersonal trust, team leader support, rewards, and knowledge sharing mechanisms on knowledge sharing in project teams. VINE, 20(2), 214-236. 